\title{
Postsecondary Teachers
}

National Cancer Institute

\section{Source}

National Cancer Institute. Postsecondary Teachers. NCI Thesaurus. Code C122499.

Postsecondary teachers instruct students in a wide variety of academic and vocational subjects beyond the high school level. They also conduct research and publish scholarly papers and books. 